\title{
IMPLEMENTATION OF COURSE REVIEW HORAY LEARNING MODEL IN SCIENCE SUBJECTS IN GRADE IV OF SD NEGERI BANGUNREJO
}

\author{
Aulia Citra $^{1}$, Dian Samitra ${ }^{2}$, Tio Gusti Satria ${ }^{3}$ \\ ${ }^{1,2,3}$ STKIP-PGRI Lubuklinggau \\ auliacitrah@gmail.com
}

DOI: https://doi.org/10.21107/Widyagogik/v8i2. 8969

Received November 04, 2020; Revised November 10, 2020; Accepted January 21, 2021

\section{Abstract}

This thesis aims to know the completed learning results of students after the study model of Course Review Horay applied to the science subjects of grade IV SD Negeri Bangunrejo. The research method used by quasy-experiment. Data collection techniques in research use tests and interviews. Data analysis techniques with steps: average score and standard deviation, normality test and $z$ test. The results showed the results of studying the IPA of grade IV students of SD Negeri Bangunrejo after the Course Review Horay model was significantly completed.

Keywords : Application, Course Review Horay, IPA learning, Learning outcomes. 
53 Implementation of Course Review Horay Learning Model in Science Subjects in Grade IV of SD Negeri Bangunrejo

Aulia Citra, Dian Samitra, Tio Gusti Satria

\section{Introduction}

One of the problems in the world of education today is the problem of learning process that is still weak. The lack of learning process is due to the lack of motivation of students to develop thinking skills so that the learning process in the classroom is only centered on the teacher without involving the student. Eventually students are only required to memorize, remember and hoard various information without understanding the information they remember to be associated with daily life (Sanjaya, 2006:1).

One of the subjects with such a learning process is science subjects. In the process of learning IPA should be designed in such a way that students feel happy, happy, and do not feel bored when learning. Science learning trains students to have basic science process skills and scientific attitudes, so that it takes a learning that not only does the student act as the recipient but the student must experience his own experience in understanding the science, so that it can ultimately be applied in daily life (Kumala, 2016:11).

Based on the preliminary observations conducted by the authors at SD Negeri Bangunrejo on July 23,2020, the average grade III students achieved the average grade 59.72 midterm exams in 2019/2020, the science subjects of grade III students only reached 59.72 while the Minimum Completedness Criteria (KKM) set by the school for science subjects was 65. 23 (69.69\%) students with an average score of 55.65 and completed students as many as $10(30.30 \%) 69.10$ out of all grade III students, which is 33 students. Low science learning results based on observations and interviews conducted by the author with Mrs. Anita Sari as a grade IV teacher of SD Negeri Bangunrejo, due to factors found among others, lack of interest in reading in students, how to learn students are still like listening, recording carefully without being required to understand it, students are less enthusiastic to follow science lessons and learning is still centered on teachers.

Low learning outcomes are also due to the lack of active students in the learning process in the classroom. The lack of active students in the learning process in the classroom results in students' understanding of low learning. This is due to the lack of competence of teachers in the learning process. Teachers are expected to be able to master teaching materials and learning strategies, without that, all efforts to improve the quality of education will not achieve optimal results. In addition, teachers should be able to motivate their students to always be passionate about learning.

One of the models that can be used to make the learning atmosphere interesting is the Learning Course Review Horay model. Course Review Horay learning model is perfect for arousing students' passion and interest in learning, because in this model there is a quiz game that can excite the spirit of learning. According to Huda (2013), Course Review Horay learning model can create a fun classroom atmosphere because any student who can answer correctly is required to shout hooray or other yel-yel that is liked and can test students' understanding in answering questions. 
Course Review Horay Learning Model Steps according to Kurniasih (2016) are:

1. Create heterogeneous groups with members of 4-5 people.

2. The teacher presents or explains the subject matter.

3. Give students a chance to ask questions.

4. Ask students to create boxes 9 or 16 or 25 according to their needs and each box is filled with numbers according to each student's taste as a form of testing students' understanding

5. The teacher reads the question randomly and the student writes the answer in the box according to the number mentioned by the teacher and is immediately discussed, if it is properly filled in the correct sign $(v)$ and if wrongly given the wrong sign $(\mathrm{x})$.

6. Students who have got a sign $(v)$ must shout hooray or other yel-yel.

7. Students' grades are calculated from the correct answers obtained.

8. Closed

Shoimin (2014), suggested that Course Review Horay learning model is one of cooperative learning models, namely learning activities by grouping students into small groups. This study can test students' concept understanding using a box filled with questions and numbered to write down the answers. The most earlier group got the right sign directly shouting hooray or other yel-yel.

The advantages of Course Review Horay learning model according to Suprijono (2015) are as follows:

1. Encourage students to engage in the learning process

2. Not boring because it is interspersed with a bit of entertainment so the atmosphere of the class is not stressful

3. Students are more eager to learn

4. Train group cooperation

Based on the statement, it can be concluded that Course Review Horay learning model can make students excited in learning and involved in the learning process and can make the learning atmosphere interesting. Course Review Horay learning model also has the benefit of training cooperation skills in groups.

\section{Method}

The research method used in this study is a pseudo-experiment that is an experiment conducted without the absence of a comparative class. The research design used in this study is pre-test and post-test one group design. In this design has only 2 measurement data namely pretest $(\mathrm{O} 1)$ and post-test measurement $(\mathrm{O} 2)$. The design of the study can be seen in Table 1. 
Table 1. Pretest-Posttest one Group Design

\begin{tabular}{|c|c|c|c|}
\hline Group & Pre-test & Treatment & Post-test \\
\hline Experiment & 01 & $\mathrm{X}$ & $\mathrm{O} 2$ \\
\hline
\end{tabular}

(Arikunto, 2010:124)

Sampling is done with saturated sampling technique, this is because in SD Negeri Bangunrejo only has one class at grade IV level then the sample of research is the entire grade IV with 32 students.

The variables in this study consist of two variables: a free variable and a bound variable. The free variable in this study is the Course Review Horay learning model, while the bonded variable is the result of studying IPA.

The data collection in this study uses a test method, with intruen data collection test ipa learning results. The tests given in the form of pre-test and post-test are carried out to measure the initial ability of the student and the final ability of the student after applying the learning model of Course Review Horay. The problem used is the multiple choice of 14 questions, where the question has been tested validity, reliability, difficulty level and differentiating power.

The data obtained in this study was further analyzed with parametric statistical analysis. Before the hypothesis analysis is done preceded by looking for the average value and the standard deviation, then testing normality. Data normality tests are performed to find out what normal pre-test and post-test distributed data is not. Test the normality of the data using chi-squared analysis. The research hypothesis was tested using the z-test formula.

\section{Result and Discussion}

\section{Research Results}

Pretest

The implementation of this pre-test is used to determine the initial ability that students have in the sound material and its association with the auditory senses. The problem used is the multiple choice of 14 questions, where the question has been tested validity, reliability, difficulty level and differentiating power. The initial ability referred to in this study was the initial knowledge that students had before being given learning with sound materials and their association with the auditory senses with the Course Review Horay learning model. 
The initial test results are the initial ability of students in learning without using Course Review Horay learning model before taking part in learning with sound material and its association with the auditory senses. The average $(x)$ and the standard deviation (s) of the initial test score can be seen in Table 2 .

Table 2. Recapitulation of Pre-test Results

\begin{tabular}{|c|c|c|}
\hline No & Category & Description \\
\hline 1 & Minimum Value & 29 \\
\hline 2 & Maximum Value & 64 \\
\hline 3 & Average Value & 46,21 \\
\hline 4 & Standard Deviation & 19,16 \\
\hline
\end{tabular}

Post-Test

The implementation of the research at the last meeting was conducted final tests (Post-test) conducted with the aim of knowing the final ability of students after being given learning using the Learning Model Course Review Horay. The question given in the form of multiple options amounts to 14 questions.

From the calculation of the average recapitulation of values and standard deviations from post-test results can be seen in Table 3 .

Table 3.Recapitulation of Post-Test Results

\begin{tabular}{|l|c|c|}
\hline No & Category & Description \\
\hline 1 & Minimum Value & 57 \\
\hline 2 & Maximum Value & 93 \\
\hline 3 & Average Value & 75,45 \\
\hline 4 & Standard Deviation & 25,79 \\
\hline
\end{tabular}

The average value and percentage of learning completion can be seen in the Figure 1. 


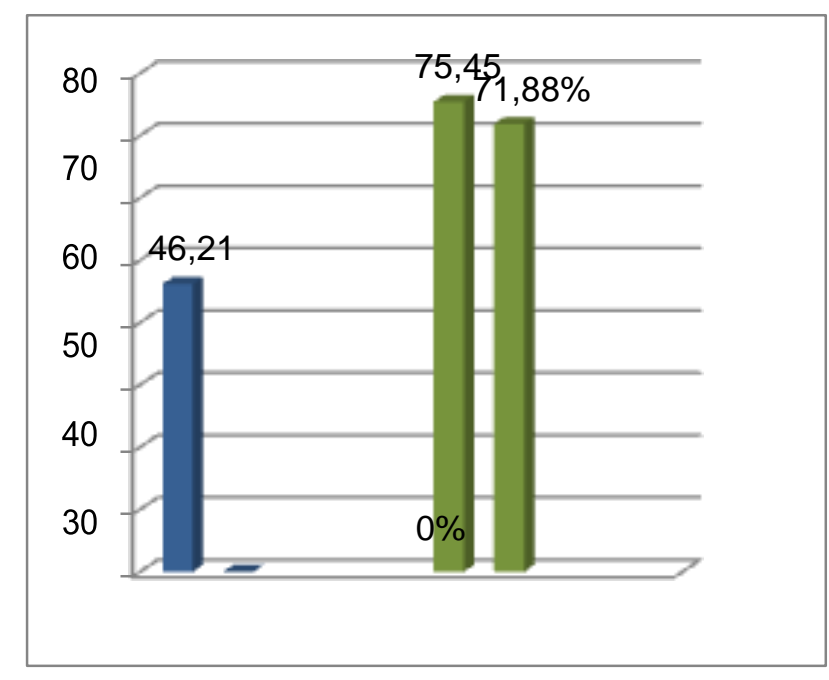

Figure 1. Graph of Average Value and Learning Completedness

\section{Data Analysis}

\section{a. Normality Test}

Based on the provision stipulated on the test of data normality with a significant level $\alpha=0.05$, if you $\leq$ the data, then each data is distributed normally. The recapitulation of the results of the Post-test normality calculation can be seen in Table 4 .

Table 4. Recapitulation of Post-Normality Test Results

\begin{tabular}{|c|c|c|c|c|}
\hline Class & $\boldsymbol{\chi}_{\text {hitung }}^{2}$ & $\mathbf{d k}$ & $\boldsymbol{\chi}_{\text {tabel }}^{2}$ & Description \\
\hline $\begin{array}{r}\text { Post- } \\
\text { test }\end{array}$ & 10,835 & 5 & 11,070 & Normal \\
\hline
\end{tabular}

Furthermore Zhitung is compared to Ztabel. Ztabel value with significant level $\alpha=$ 0.05 is 1.64 while zhitung value $=2.29$ because Zhitung (2.29) $>$ Ztabel (1.64) then Ho is rejected and $\mathrm{Ha}$ is accepted. Thus, the average student's study results after the application of the Course Review Horay learning model are greater than or equal to 65 $(\mu \geq 65)$. This shows that after the learning process by using the Course Review Horay model the results of the IPA study of grade IV students of SD Negeri Bangunrejo are significantly completed. Hypothetical test results can be seen in Table 5 .

Table 5. Recapitulation of Post-test Data Hypothesis Results

\begin{tabular}{|c|c|c|c|}
\hline Tes & $\mathbf{Z}_{\text {hitung }}$ & $\mathbf{Z}_{\text {tabel }}$ & Description \\
\hline Post- test & 2,29 & 1,64 & Zhitung $>$ Ztabel, Ha accepted \\
\hline
\end{tabular}




\section{Discussion}

This research process was conducted as many as 5 meetings, with details of one pre-test, three learning process meetings by applying the Course Review Horay learning model and one meeting as a post-test implementation. The data of the results of the study is obtained from the data of the preliminary ability (pre-test) and the final ability test (post-test) which is useful to know the results of learning after the application of the Course Review Horay model..

After conducting the initial test, the implementation of learning with Course Review Horay model in this study was conducted three meetings. The results of each meeting are described below.

\section{First Meeting}

The first meeting before the author's study explained how to learn using Course Review Horay model as well as how the provisions of creating boxes and filling in numbers on the box. Then the author asks each group to set up yel-yel. After the explanation of the learning process by applying the model is done with the first step, the author explains the source material of the sound and the process of the sound from the sound source to the auditory senses. Then the author invites students to ask if there is anything that is not yet understood from the material. After studying the material, the authors formed a group of 5-6 people in a heterogeneous group based on the student's ability. After forming a group, the author gives an example of creating a box image on the board and then after that the author shares a blank paper with each group. The author asks students to draw 9 boxes on the shared paper and then each box is filled with numbers according to their individual tastes and gives each group the opportunity to prepare yel-yel. After the group is given the opportunity to create a box and yel-yel the author reads the question randomly and each group writes on the worksheet. Students try to discuss with their friends about the questions that have been written on the worksheet. After students discussed, the authors read the questions randomly, each group raising their hands to answer questions. For groups that have the opportunity to answer and are correct, they must write the correct sign $(v)$ and wrongly mark $(x)$ in the box provided. Groups that have got the correct sign $(V)$ vertically or horizontally or diagonally should shout hooray. At the end of the first meeting, the author evaluated the learning process using Course Review Horay model. During the learning process, students are not used to learning using Course Review Horay learning model so many students still feel a little confused, the atmosphere of the class becomes noisy because students ask a lot with their friends. At the end of the activity students and teachers together concluded the subject matter. The teacher delivered the material that will be discussed at the next meeting. The teacher informs that at the next meeting the learning will be the same using the Course Review Horay model.

\section{Second Meeting}


In the second meeting, the author recalled how to learn by using Course Review Horay model. The author begins the learning process by applying the model and explaining the material about the nature of ear-related sounds as hearing devices. This second meeting all students began to understand how to learn by using Course Review Horay model. Students no longer ask questions with friends. However, there are obstacles during the application of the model, the atmosphere is a little noisy when students raise their hands to answer questions and at the time of the pronunciation of hooray. These barriers can be overcome by giving attention and direction to students that should not cause an atmosphere that is not conducive. If the student violates, it will be given a reduction in the score or grades that the group has obtained.

\section{Third Meeting}

The third meeting, the author began the learning process by applying the Horay Course Review model conducted and explaining the material benefits of the depositing and absorption of sound as well as hearing loss and how to treat the ears properly. The third meeting, students enjoyed the learning process by using the Course Review Horay model. Students are very happy and motivated to learn because of the fun learning atmosphere and learning

atmosphere while playing quizzes so that students do not get bored. Although they enjoy learning using Course Review Horay model, there are still students who are shy and afraid of being wrong to answer questions.

Student learning outcomes are complete because through the Course Review Horay learning model: 1) Students engage in the learning process, 2) Students are more passionate about learning, 3) Learning is not monotonous (Shoimin,2014:55).

Based on research conducted by the authors, it was obtained that the use of Course Review Horay model can be used as an alternative in the learning process when students experience boredom in learning. So students are more actively seeking information about the material to be learned from a variety of sources that allow students to discover and build their own knowledge. Meanwhile, writers are more of a facilitator and control over what they are and what students need to work on and how to address the problems they find.

\section{Conclusion}

\section{Conclusion}

Based on the results of the research conducted and discussed, the average Posttest value was 75.45 with a complete percentage of $71.88 \%$ and $z$ test calculation obtained Zhitung > Ztabel $(2.29>1.64)$ then Ho was rejected and Ha was accepted. Then it can be concluded that the results of studying the IPA of grade IV students of SD Negeri Bangunrejo after the completion of the Course Review Horay model are significantly complete. 


\section{Suggestion}

Based on the results of the study as well as conclusions, the advice that can be given by researchers is as follows:

1. Learning using Course Review Horay model, can train students to be more active and ready to follow the learning process in science lessons, because if the student actively asks and is ready with any questions that will be given by the teacher, the student will be more confident to solve the problems he encounters in the learning process.

2. Teachers are expected to improve the science learning process by using appropriate learning models so that the results are achieved in accordance with the objectives. One of them uses the Course Review Horay model.

3. Schools must provide support and opportunities to teachers as educators to use learning models when carrying out the learning process in order to improve the quality of education.

4. Researchers are expected to motivate themselves in developing knowledge about the use of Course Review Horay model in the learning process so as to create an interesting learning atmosphere.

\section{References}

Arikunto, S. (2010). Prosedur Penelitian Suatu Pendekatan Praktik. Jakarta: Rineka Cipta

Huda, M. (2013). Model-model Pengajaran dan Pembelajaran. Yogyakarta: Pustaka Pelajar

Kumala, F. N. (2016). Pembelajaran IPA Sekolah Dasar. Malang: Ediide Infografika

Kurniasih, I. (2016). Model Pembelajaran. Yogyakarta: Kata Pena

Sanjaya, W. (2006). Strategi Pembelajaran Berorientasi Standar Proses Pendidikan. Jakarta: Kencana Prenadamedia Group

Shoimin, A. (2014). 68 Model Pembelajaran Inovatif dalam Kurikulum 2013. Yogyakarta: Ar- Ruzz Media

Suprijono, A. (2015). Cooperative Learning Teori \& Aplikasi Paikem. Yogyakarta: Pustaka Pelajar 